\title{
Normative data for Italian Deese/Roediger-McDermott lists
}

\author{
Vittorio Maria Iacullo ${ }^{1}$ Francesco Saverio Marucci $^{1}$
}

Published online: 19 March 2015

(C) Psychonomic Society, Inc. 2015

\begin{abstract}
The present study provides norms for Deese/ Roediger-McDermott (DRM) lists that were used to create false memories in native speakers of Italian. The word lists reported in this article are based on the DRM lists that have been used extensively to examine illusory memories in English speakers (Deese in Journal of Experimental Psychology, 58, 17-22, 1959; Roediger \& McDermott in Journal of Experimental Psychology: Learning, Memory, \& Cognition, 21, 803814, 1995). We translated the 24 critical lures from 24 English DRM lists and created semantically associated Italian word lists that were then normed with native Italian speakers. Overall, the participants recalled $63 \%$ of the list items and $22 \%$ of the critical lures with the word lists developed. In addition, $56 \%$ of the list items and $82 \%$ of the critical lures were recognized by the participants. The present study provides a set of Italian lists that can be used by researchers interested in evaluating false memories in Italian-speaking participants.
\end{abstract}

Keywords DRM paradigm · Italian · False memories ·

Recall $\cdot$ Recognition

The Deese/Roediger-McDermott (DRM) paradigm (Deese, 1959; Roediger \& McDermott, 1995) has been widely used to study false memories. The typical procedure involves presenting participants with a sequence of words that are semantically related to a common associate word (i.e., the critical lure). At test, the participants frequently remember the critical lure, despite the fact that it was never presented. For example, they may be presented with a list of words, such as sour, candy, sugar, bitter, good, taste, and so forth, and when tested, they will often remember the critical lure sweet, despite the fact that sweet was never presented. This general finding has been replicated in a number of studies that have established

Vittorio Maria Iacullo

vittoriomaria.iacullo@uniroma1.it

1 Sapienza University of Rome, Rome, Italy that the DRM effect is quite robust (see Gallo \& Roediger, 2001; Marsh, McDermott, \& Roediger, 2004; Norman \& Schacter, 1997; Payne, Elie, Blackwell, \& Neuschatz, 1996; Seamon, Luo, \& Gallo, 1998; Stadler, Roediger, \& McDermott, 1999). Roediger and McDermott took Deese's six strongest lists and demonstrated robust false recall and recognition. In their second experiment, they developed an additional 18 lists, providing a total of 24 lists. Their results showed false recognition equal to veridical recognition and a level of false recall that was similar to that of correct recall. Stadler, Roediger, and McDermott conducted a norming study showing that the different lists, although constructed in similar manners, varied considerably in the probabilities at which the critical lure was falsely recalled or recognized. Subsequent studies identified some factors that determine false memories in the DRM paradigm (Brainerd, Yang, Reyna, Howe, \& Mills, 2008; Madigan \& Neuse, 2004; Roediger, Watson, McDermott, \& Gallo, 2001).

The DRM paradigm has been limited to English-speaking participants, with few studies examining illusory memories in other languages (for exceptions, see Anastasi, De Leon, \& Rhodes, 2005; Anastasi, Rhodes, Marquez, \& Velino, 2005; Pérez-Mata, Read, \& Diges, 2002; Zeelenberg \& Pecher, 2002). Pérez-Mata et al. tested Spanish speakers using associative Spanish lists. Zeelenberg and Pecher presented participants with items from the DRM lists that had been directly translated into Dutch. Anastasi, De Leon, and Rhodes (2005; Anastasi, Rhodes, et al., 2005) used a similar method by directly translating six of the DRM lists into Spanish, Japanese, and German, in order to test foreign exchange students in their native languages. To our knowledge, normative data for Italian DRM lists comparable to those reported by Stadler et al. (1999), for English, and Anastasi, De Leon, and Rhodes, for Spanish, have not yet been provided. Considering the Italian equivalents of the critical lures used by Roediger and McDermott (1995) and Stadler et al., we developed a set of 24 Italian word lists for the present study. Then we presented each of these 24 lists to Italian-speaking individuals and tested their memory, using both recall and recognition tests 
and measures. Finally, we present normative data for both the list items and the critical lures for each of the lists developed.

\section{Method}

\section{Participants}

All the participants reported Italy as their country of origin and Italian as their native language. Ninety participants produced association norms, which were then used to create Italian DRM lists. Their average age was $M=28.94$ years $(S D=$ 11.06). Once the 24 DRM lists had been created, we tested them using 68 additional Italian students of Sapienza University of Rome. We split the sample of 68 participants into two groups of 34 that were used to norm the Italian lists using recall and recognition tests. All of the 68 participants lived in Italy and reported Italian as their native language. The average age of the participants was $M=23.93$ years $(S D=1.98$ ), and they were tested in groups of up to eight people each.

\section{Materials and procedure for association norms}

The Italian lists in the present study were constructed using the same general method of Anastasi, De Leon, and Rhodes (2005). Anastasi, De Leon, and Rhodes had employed a PowerPoint presentation of the lists; instead, we used an online survey to present the participants with the Italian equivalents of the 24 critical lures one at a time. We collected the responses of 90 participants in a discrete association task. Participants were instructed to write in a textbox the first word that came to mind. All of the instructions were given in Italian. We then constructed 24 DRM lists from the 15 most frequent responses to each of the 24 critical lures that had been used as cues in the preceding discrete association task. The Italian DRM lists developed are provided in the Appendix, along with each item's approximate English translation. Some words had to be replaced by the next most frequent associate, due to replication in other lists. ${ }^{1}$

\section{Materials and procedure for the 24 DRM lists}

Twelve lists were presented to each of the two groups of 34 participants, in order to assess the likelihood that each list would produce false memories of the critical lure during recall and recognition testing (see the Appendix).

Several sessions of the same experiment were conducted in a room of the Psychology Faculty at Sapienza University of Rome. The participants who were tested in order to norm the

\footnotetext{
${ }^{1}$ The appendix includes the 24 lists, divided into two homogeneous groups (A and B). Our interest in the present study was to avoid word repetitions within each list and not between groups A and B. Indeed, participants were divided into two groups and saw either the 12 lists of group A or the 12 lists of group B.
}

lists were instructed to view each word as it was presented on a $4 \mathrm{~m}^{2}(2 \times 2)$ screen for $2 \mathrm{~s}$ and were informed that their memory for these words would be tested. ${ }^{2}$ Participants then viewed each word of the first list presented in 80-point font, centered on the screen. Then participants were instructed to write down all of the words that they could remember. This was repeated for all 12 lists of each group. After the final recall test, the participants were instructed to compile a 72-item, paper-based, yes-no recognition test that contained 36 list items (three from each of the 12 presented lists), the 12 critical lures from the presented lists, and 24 nonlist items. The nonlist items were unrelated to the items in the lists and to the critical lures. All of the instructions were given in Italian.

\section{Results}

We used SPSS software for our data analysis.

\section{Recall data}

The list and critical lure recall data for each Italian list are presented in Table 1. This table also provides the proportions of list items and critical lures recalled in the English and Spanish lists normed in previous studies (Anastasi, De Leon, \& Rhodes, 2005; Roediger \& McDermott, 1995; Stadler et al., 1999). The data from the Italian lists showed great variability in the probabilities that the different lists would produce illusory memories. For example, the uomo list resulted in very few critical lures being recalled, whereas lento led to more critical lures being recalled (.71) than list items (.59). Overall, the Italian lists were more likely to produce correct recall $(M=.63, S D=.21)$ than critical recall $(M=.22, S D=.37)[t(23)=.13 .11, p<.001]$.

The level of recall in the present study differed somewhat from those reported by Stadler et al. (1999) and Anastasi, De Leon, and Rhodes (2005), but the patterns were similar. For example, Stadler et al. found that a greater proportion of list items (.60) were recalled than critical lures (.40). Likewise, for Anastasi, De Leon, and Rhodes, the list item proportion (.53) was higher than the critical lure proportion (.30).

As in Stadler et al. (1999), the lists from the present study were split into the 12 lists most likely to lead to false memories and the 12 least likely to result in false

\footnotetext{
${ }^{2}$ Previous studies had demonstrated that presenting list items in the auditory modality results in an increase in false recall (Gallo, McDermott, Percer, \& Roediger, 2001; Smith \& Hunt, 1998), as compared with a visual mode of presentation. This "modality effect" in false memories is caused by participants' resource availability. In fact Smith and Engle (2011) demostrated that false recall was reduced in the visual study presentation condition relative to the auditory condition for participants with higher working memory capacity, but not for participants with lower working memory capacity. In the present study, we utilized a visual presentation modality similar to those in other norming studies (Anastasi, De Leon, \& Rhodes, 2005; Stadler et al., 1999).
} 
Table 1 Mean proportions of critical lures and list items recalled, for each Italian list in the present study; for the English list normed by Stadler, Roediger, and McDermott (1999) and Roediger and McDermott (1995); and for the Spanish list normed by Anastasi, De Leon, and Rhodes (2005)

\begin{tabular}{|c|c|c|c|c|c|c|c|c|}
\hline \multirow[t]{4}{*}{ List } & \multicolumn{4}{|c|}{ Italian } & \multicolumn{2}{|l|}{ English } & \multicolumn{2}{|l|}{ Spanish } \\
\hline & \multicolumn{4}{|c|}{ Present Study } & \multicolumn{2}{|c|}{ Roediger \& McDermott, 1995*; Stadler et al., 1999} & \multicolumn{2}{|c|}{ Anastasi et al., 2005} \\
\hline & \multicolumn{2}{|c|}{ Critical Lures } & \multicolumn{2}{|c|}{ List Items } & \multirow[t]{2}{*}{ Critical Lures } & \multirow[t]{2}{*}{ List Items } & \multirow[t]{2}{*}{ Critical Lures } & \multirow[t]{2}{*}{ List Items } \\
\hline & $M$ & $S D$ & $M$ & $S D$ & & & & \\
\hline Lento (slow) (despacio) & .71 & .46 & .59 & .26 & .42 & .53 & .00 & .59 \\
\hline Dolce (sweet) (dulce) & .44 & .49 & .60 & .23 & .54 & .63 & 62 & .42 \\
\hline Freddo (cold) (frio) & .41 & .47 & .63 & .18 & .44 & .61 & .52 & .60 \\
\hline Gomma (rubber) & .29 & .46 & .58 & .19 & .32 & .53 & & \\
\hline Amaro (bitter) & .26 & .43 & .51 & .24 & $.01 *$ & $.68^{*}$ & & \\
\hline Giustizia (justice) & .26 & .43 & .68 & .15 & $.30 *$ & $.59 *$ & & \\
\hline Sedia (chair) (silla) & .24 & .43 & .66 & .19 & .54 & .64 & .44 & .58 \\
\hline Lampada (lamp) & .24 & .42 & .59 & .25 & $.14 *$ & $.61^{*}$ & & \\
\hline Rabbia (anger) (enojo) & .21 & .41 & .69 & .27 & .49 & .50 & .20 & .46 \\
\hline Bandiera (flag) & .21 & .40 & .64 & .17 & .31 & .63 & & \\
\hline Fiume (river) (río) & .21 & .40 & .69 & .19 & .42 & .64 & .38 & .55 \\
\hline Fumo (smoke) & .21 & .40 & .57 & .20 & .54 & .64 & & \\
\hline Ladro (thief) (ladrón) & .21 & .40 & .64 & .23 & .23 & .61 & .24 & .51 \\
\hline Penna (pen) & .21 & .39 & .70 & .15 & .35 & .36 & & \\
\hline Ragno (spider) (araña) & .18 & .39 & .56 & .18 & .37 & .62 & .52 & .44 \\
\hline Soffice (soft) (suave) & .18 & .40 & .61 & .21 & .46 & .59 & .12 & .51 \\
\hline Ago (needle) (aguja) & .18 & .37 & .75 & .19 & .52 & .60 & .26 & .51 \\
\hline Alto (high) (alto) & .18 & .37 & .53 & .22 & .26 & .58 & .68 & .48 \\
\hline Pane (bread) (pan) & .15 & .36 & .66 & .17 & .31 & .55 & .16 & .52 \\
\hline Piede (foot) (pie) & .12 & .27 & .64 & .26 & .35 & .64 & .28 & .61 \\
\hline Musica (music) (musica) & .09 & .26 & .57 & .22 & .34 & .59 & .38 & .55 \\
\hline Re (king) (rey) & .06 & .22 & .68 & .18 & .10 & .65 & .12 & .61 \\
\hline Ragazza (girl) (niña) & .03 & .17 & .67 & .27 & .32 & .67 & .30 & .50 \\
\hline Uomo (man) (hombre) & .03 & .16 & .63 & .26 & .24 & .56 & .18 & .56 \\
\hline Average & .22 & .37 & .63 & .21 & $.35(.16)$ & $.59(.08)$ & $.32(.19)$ & $.53(.06)$ \\
\hline
\end{tabular}

We calculated means and standard deviations just of data reported in this table. Thus, those values do not refer to means and standard deviations reported in the cited original articles. To know these values, see the recall results paragraph

memories. List recall was not significantly higher for the bottom 12 lists $(M=.63, S D=.06)$ than for the top 12 lists $(M=.62, S D=.05)[t(23)=0.66, p=.513]$. However, not surprisingly, critical lure recall was higher for the top 12 lists $(M=.31, S D=.15)$ then for to the bottom 12 lists $(M=.13, S D=.07)[t(23)=3.71, p=.001]$. Furthermore, list recall was significantly greater than critical lure recall for both the top 12 lists $[t(11)=6.31, p<$ $.001]$ and the bottom 12 lists $[t(11)=19.22, p<.001]$.

\section{Recognition data}

The list item and critical lure recognition data for each Italian list are presented in Table 2. This table also provides the proportions of list items and critical lures recalled in the English and Spanish lists normed in previous studies (Anastasi, De Leon, \& Rhodes, 2005; Roediger \& McDermott, 1995; Stadler et al., 1999). The recognition data showed that $97 \%$ of the participants tested with the soffice list recognized the critical lure, whereas $67 \%$ of the participants recognized the critical lure when given the uomo and ragazza lists. Overall, the participants were significantly more likely to recognize critical lures $(M=.82, S D=.11)$ than to recognize list items $(M=.56, S D=.16)[t(23)=5.89, p<.001]$. This evidence is consistent with that obtained by Stadler et al., who reported that critical lures were falsely recognized $68 \%$ of the time, whereas list items were correctly recognized $70 \%$ of the time. As with the recall data, the recognition data were also split into the top 12 and bottom 12 lists, on the basis of the probabilities that the critical lure would be recognized. The participants 
Table 2 Mean proportions of critical lures and list items recognized, for each Italian list in the present study; for the English lists normed by Stadler, Roediger, and McDermott (1999) and Roediger et al. (2001); and for the Spanish list normed by Anastasi, De Leon, and Rhodes (2005)

\begin{tabular}{|c|c|c|c|c|c|c|c|c|}
\hline \multirow[t]{4}{*}{ List } & \multicolumn{4}{|c|}{ Italian } & \multicolumn{2}{|l|}{ English } & \multicolumn{2}{|l|}{ Spanish } \\
\hline & \multicolumn{4}{|c|}{ Present Study } & \multicolumn{2}{|c|}{ Roediger et al., 2001*; Stadler et al., 1999} & \multicolumn{2}{|c|}{ Anastasi et al., 2005} \\
\hline & \multicolumn{2}{|c|}{ Critical Lures } & \multicolumn{2}{|c|}{ List Items } & \multirow[t]{2}{*}{ Critical Lures } & \multirow[t]{2}{*}{ List Items } & \multirow[t]{2}{*}{ Critical Lures } & \multirow[t]{2}{*}{ List Items } \\
\hline & $M$ & $S D$ & $M$ & $S D$ & & & & \\
\hline Soffice (soft) (suave) & .97 & .47 & .67 & .09 & .81 & .63 & .54 & .73 \\
\hline Fumo (smoke) & .96 & .49 & .64 & .18 & .73 & .84 & & \\
\hline Lento (slow) (despacio) & .93 & .49 & .97 & .25 & 69 & .56 & .36 & .76 \\
\hline $\operatorname{Re}$ (king) (rey) & .92 & .43 & .23 & .27 & .27 & 69 & .72 & .77 \\
\hline Bandiera (flag) & .92 & .50 & .40 & .21 & .60 & .62 & & \\
\hline Penna (pen) & .91 & .50 & .56 & .22 & .57 & .68 & & \\
\hline Sedia (chair) (silla) & .89 & .50 & .54 & .29 & .74 & .74 & .52 & .69 \\
\hline Ladro (thief) (ladrón) & .89 & .45 & .72 & .30 & .70 & .71 & .94 & .67 \\
\hline Fiume (river) (río) & .88 & .49 & .59 & .29 & .67 & .76 & .74 & .81 \\
\hline Alto (high) (alto) & .87 & .32 & .88 & .30 & .72 & .77 & .94 & .73 \\
\hline Ago (needle) (aguja) & .85 & .49 & .38 & .34 & .68 & .71 & .70 & .91 \\
\hline Musica (music) (musica) & .85 & .51 & .51 & .34 & .69 & .59 & .82 & .76 \\
\hline Freddo (cold) (frio) & .81 & .44 & .74 & .37 & .84 & .79 & .72 & .85 \\
\hline Giustizia (justice) & .81 & .39 & .82 & .32 & $.76^{*}$ & & & \\
\hline Rabbia (anger) (enojo) & .80 & .33 & .64 & .35 & .79 & .69 & .54 & .51 \\
\hline Lampada (lamp) & .79 & .49 & .64 & .31 & $.63^{*}$ & & & \\
\hline Gomma (rubber) & .77 & .01 & .44 & .41 & .67 & .64 & & \\
\hline Ragno (spider) (araña) & .76 & .50 & .44 & .41 & .58 & .71 & .92 & .75 \\
\hline Amaro (bitter) & .71 & .33 & .76 & .44 & $.26^{*}$ & & & \\
\hline Pane (bread) (pan) & .71 & .17 & .44 & .44 & .64 & .51 & .34 & .67 \\
\hline Piede (foot) (pie) & .69 & .45 & .25 & .42 & .62 & .59 & .76 & .74 \\
\hline Dolce (sweet) (dulce) & .69 & .33 & .88 & .39 & .78 & .68 & .94 & .82 \\
\hline Uomo (man) (hombre) & .67 & .40 & .19 & .42 & .61 & .80 & .70 & .72 \\
\hline Ragazza (girl) (niña) & .67 & .45 & .28 & .47 & .58 & .88 & .70 & .71 \\
\hline Average & .82 & .41 & .56 & .33 & $.65(.14)$ & $.69(.09)$ & $70(.19)$ & $.74(.09)$ \\
\hline
\end{tabular}

We calculated means and standard deviations of the data reported in this table. Thus, those values do not refer to means and standard deviations reported in the cited original articles. For these values, see the recognition results paragraph

recognized critical lures more often for the top 12 lists $(M=$ $.90, S D=.04)$ than for the bottom 12 lists $(M=.74, S D=.05)$ $[t(11)=8.35, p<.001]$. The list item mean for the top 12 lists $(M=.59, S D=.20)$ was not significantly different from the mean for the bottom 12 lists $(M=.54, S D=.23)[t(11)=0.52$, $p=.605]$. Similarly to the recall data, the recognition data were comparable to those from the English and Spanish lists. In fact, Stadler et al. reported that their top lists resulted in $71 \%$ of list items and $77 \%$ of critical lures being recognized, whereas their bottom lists resulted in $74 \%$ of list items and $55 \%$ of critical lures being recognized. Similarly, the Spanish lists (Anastasi, De Leon, \& Rhodes, 2005) provided $77 \%$ of list items and $84 \%$ of critical lures being recognized for the top lists, as compared to $70 \%$ of list items and $54 \%$ of critical lures for the bottom lists.

\section{Correlation data}

Pearson correlations were calculated for the mean proportions of critical lures and list items recalled and recognized by each participant.

These results showed a significant correlation between critical lure recall and critical lure recognition $(r=.73, p<.001)$, since the participants tended to produce false memories at similar levels in the recall and recognition tasks. Also, a significant moderate correlation between list item recall and list item recognition $(r=.25, p<.05)$ was found. These data are coherent with those of Stadler et al. (1999), who found the recall versus recognition correlation to be higher for critical lures (.77) than for list items (.52). Anastasi, De Leon, and Rhodes (2005) instead reported a correlation between recall 
and recognition only for list items (.34). Furthermore, as has been argued by previous researchers (e.g., Seamon et al., 1998; Stadler et al., 1999), recognition performance could be influenced by the previous recall task. Additional correlations were computed to determine whether false recall and false recognition among the present Italian norms were related to results from the English norms published by Stadler et al. and the Spanish norms published by Anastasi, De Leon, and Rhodes. These data revealed a moderate correlation between critical lure recognition in the present norms and the Anastasi, De Leon, and Rhodes Spanish norms $(r=.43, p=.05)$. In a similar analysis for critical lure recall, in which these norms were compared, no significant correlations were observed.

\section{Discussion}

In the present study, we created a set of Italian associative lists using native Italian speakers. To our knowledge, no other study has developed Italian associative lists using the DRM paradigm and provided normative data for recall and recognition of these lists. Such normative data can be useful for researchers interested in investigating illusory memories in Italian speakers using the DRM paradigm (Deese, 1959; Roediger \& McDermott, 1995). As Anastasi, De Leon, and Rhodes (2005) suggested, another potentially important use of these lists will be to conduct research investigating bilinguals, in order to help delineate theoretical explanations for the false memory effect. Furthermore, in the present study we used the general method proposed by Anastasi, De Leon, and Rhodes for converting the DRM lists into the Italian language. These results demonstrated the robustness of the DRM false memory paradigm in other languages. The normative data for the present Italian lists are similar to those for the English lists normed by Stadler et al. (1999) and the Spanish lists normed by Anastasi, De Leon, and Rhodes. The effectiveness of the lists in producing false memories showed variability, with some lists demonstrating high levels of false recall or recognition, whereas other lists were much less likely to lead to false memories. For example, the lento list resulted in $71 \%$ of the participants recalling the critical lure, whereas $3 \%$ of the participants recalled the critical lures for the uomo and ragazza lists. The latter two were the lists most unlikely to produce false recognition; in contrast, soffice was the list most likely to result in false recognition $(M=97 \%)$. Finally, we demonstrated a significant correlation between those lists that led to high levels of false recall and those that led to false recognition. However, there were some exceptions. For example, the re list was very effective in producing false recognition $(M=.92)$, but not for producing false recall $(M=.06)$.

The false memory effect has already gained the attention of many memory researchers, but nevertheless, the majority of studies have tested English speakers using the DRM paradigm. The present study adds to the literature by providing a set of Italian lists that can be used by researchers interested in testing individuals who speak Italian. These norms will be useful for researchers interested in assessing illusory memories with the DRM paradigm.

\section{Appendix: Normed Italian word lists, with English translations in parentheses}

\section{Group $A$}

Alto (High)

Basso (Low)

Magro (Skinny)

Palazzo (Palace)

Adige (Adige)

Dritto (Straight)

Fragile (Frail)

Medio (Medium)

Gigante (Giant)

Muro (Wall)

Grattacielo (Skyscraper)

Scaffale (Shelf)

Metro (Meter)

Grado (Grade)

Palo (Pole)

Torre (Tower)

\section{Bandiera (Flag)}

Italia (Italy)

Rossa (Red)

Tricolore (Tricolor)

Vento (Wind)

Nazione (Country)

Bianca (White)

Alza (Raise)

Asta (Flagstaff)

Colore (Color)

Italiana (Italian)

Strisce (Stripes)

Cuore (Heart)

Mondiali (World Championship)

Innalzare (Raise)

Inno (Hymn)

\section{Dolce (Sweet)}

Caramella (Candy)

Amaro (Amaro)

Pasticcino (Pastry)

Tenero (Tender)

Zucchero (Sugar)

Miele (Honey) 


\begin{tabular}{|c|c|}
\hline Goloso (Greedy) & Rapina (Robbery) \\
\hline Crostata (Tart) & Assassino (Murder) \\
\hline Acre (Acrid) & Prigione (Prison) \\
\hline Sapore (Flavour) & Sbirro (Cop) \\
\hline Torta (Cake) & Pistola (Gun) \\
\hline Crema (Cream) & Carcere (Prison) \\
\hline Panna (Whipped Cream) & Crimine (Crime) \\
\hline \multicolumn{2}{|l|}{ Frutto (Fruit) } \\
\hline \multirow[t]{2}{*}{ Salato (Salted) } & Lampada (Lamp) \\
\hline & Luce (Light) \\
\hline Fiume (River) & Lume (Light) \\
\hline Foce (Mouth) & Sfregare (To Rub) \\
\hline Affluente (Tributary) & Accesa (Turned On) \\
\hline Scorrere (To Scroll) & Spina (AC Plug) \\
\hline Diga (Dam) & Voce (Voice) \\
\hline Pescare (Fishing) & Volta (Vault) \\
\hline Ponte (Bridge) & Desiderio (Desire) \\
\hline Torrente (Torrent) & Ragione (Reason) \\
\hline Corrente (Stream) & Calore (Heat) \\
\hline Flusso (Flow) & Alogena (Halogen) \\
\hline Pesce (Fish) & Lampadina (Lightbulb) \\
\hline Arno (Arno) & Aladino (Aladdin) \\
\hline Lungo (Long) & Neon (Neon) \\
\hline Valle (Valley) & Genio (Genie) \\
\hline Detriti (Debris) & Musica (Music) \\
\hline \multicolumn{2}{|l|}{ Tevere (Tiber) } \\
\hline \multirow[t]{2}{*}{ Gomma (Rubber) } & Concerto (Concert) \\
\hline & Pentagramma (Pentagram) \\
\hline Masticare (To Chew) & Radio (Radio) \\
\hline Piuma (Feather) & Ritmo (Rhythm) \\
\hline Cancellare (To Erase) & Melodia (Melody) \\
\hline Macchina (Machine) & Sassofono (Saxophone) \\
\hline Cancella (Delete) & Strumento (Instrument) \\
\hline Plastica (Plastic) & Nota (Note) \\
\hline Matita (Pencil) & Sinfonia (Symphony) \\
\hline Ruota (Wheel) & Arpa (Harp) \\
\hline Sgonfia (Deflated) & Disco (Disk) \\
\hline Bucata (Punctured) & Pianoforte (Piano) \\
\hline Ammortizzatore (Shock Absorber) & Suono (Sound) \\
\hline Denti (Teeth) & Chitarra (Guitar) \\
\hline Pneumatico (Tire) & Orchestra (Orchestra) \\
\hline \multicolumn{2}{|l|}{ Termica (Thermal) } \\
\hline \multirow{2}{*}{ Elastica (Elastic) } & Pane (Bread) \\
\hline & Caldo (Hot) \\
\hline Ladro (Thief) & Vino (Wine) \\
\hline Furfante (Villain) & Farina (Flour) \\
\hline Truffatore (Fraudster) & Lievito (Yeast) \\
\hline Rubare (To Steal) & Morbido (Soft) \\
\hline Rapinatore (Robber) & Quotidiano (Daily) \\
\hline Scippo (Snatch) & Buono (Good) \\
\hline Delinquente (Delinquent) & Forno (Oven) \\
\hline Scassinare (To Burgle) & Fragrante (Fragrant) \\
\hline Bandito (Bandit) & Pasta (Pasta) \\
\hline
\end{tabular}


Salame (Salame)

Olio (Oil)

Chilo (Kilogram)

Coltello (Knife)

Duro (Stale)

\section{Rabbia (Anger)}

Ira (Wrath)

Collera (Rage)

Furore (Fury)

Imbestialire (Enraged)

Sdegno (Disdain)

Avversione (Aversion)

Odio (Hate)

Arrabbiato (Angry)

Fastidio (Annoyance)

Malcontento (Discontent)

Prepotente (Bully)

Calma (Quiet)

Colpa (Guilt)

Malumore (Moodiness)

Paura (Fear)

\section{Ragazza (Girl)}

Carina (Cute)

Bionda (Blonde)

Bella (Beautiful)

Brava (Good)

Brutta (Ugly)

Affascinante (Fascinating)

Balia (Nanny)

Piacevole (Pleasant)

Piatta (Flat)

Giovane (Young)

Madre (Mother)

Amore (Love)

Bellezza (Beauty)

Capelli (Hair)

Allegra (Cheerful)

Sedia (Chair)

Tavolo (Table)

Legno (Wood)

Dondolo (Swinging)

Gambe (Legs)

Rotelle (Wheelchair)

Sedere (To Sit Down)

Paglia (Straw)

Poltrona (Armchair)

Riposo (Rest)

Scomoda (Uncomfortable)

Sdraio (Sun Loungers)

Sgabello (Stool)
Studio (Study)

Comoda (Comfortable)

Cucina (Kitchen)

\section{Group B}

Amaro (Bitter)

Dolce (Sweet)

Liquore (Liqueur)

Aspro (Sour)

Lucano (Lucano)

Caffè (Coffee)

Cioccolato (Chocolate)

Bocca (Mouth)

Digerire (Digest)

Acre (Acrid)

Alcolico (Alcohol)

Averna (Averna)

Gusto (Taste)

Salato (Salty)

Medicina (Medicine)

Limone (Lemon)

Freddo (Cold)

Ghiaccio (Ice)

Guanti (Gloves)

Vento (Wind)

Coperta (Blanket)

Metallico (Metallic)

Montagna (Mountain)

Neve (Snow)

Pioggia (Rain)

Monte (Mount)

Tiepido (Warm)

Coperto (Covered)

Maglione (Sweater)

Naso (Nose)

Corrente (Wind)

Sciare (Ski)

Giustizia (Justice)

Polizia (Police)

Salto (Jump)

Colle (Hill)

Colpa (Fault)

Crimine (Crime)

Cassazione (Supreme Court)

Giudice (Judge)

Privata (Private)

Tribunale (Court)

Equità (Equity)

Divina (Divine) 


\begin{tabular}{|c|c|}
\hline Ingiusta (Unjust) & Grande (Great) \\
\hline Legge (Law) & Maschile (Masculine) \\
\hline \multicolumn{2}{|l|}{ Martello (Hammer) } \\
\hline \multirow[t]{2}{*}{ Utopia (Utopia) } & Soffice (Soft) \\
\hline & Morbido (Soft) \\
\hline $\operatorname{Re}($ King) & Duro (Hard) \\
\hline Potere (Power) & Cuscino (Pillow) \\
\hline Regina (Queen) & Letto (Bed) \\
\hline Corona (Crown) & Nuvola (Cloud) \\
\hline Cavallo (Horse) & Lana (Wool) \\
\hline Monarca (Monarch) & Panna (Whipped Cream) \\
\hline Cuori (Hearts) & Piume (Feathers) \\
\hline Sudditi (Subjects) & Sfoglia (Puff Pastry) \\
\hline Monarchia (Monarchy) & Materasso (Mattress) \\
\hline Sole (Sun) & Molle (Soft) \\
\hline Trono (Throne) & Pulcino (Chick) \\
\hline Nudo (Naked) & Piumino (Down) \\
\hline Elogio (Eulogy) & Schiumoso (Frothy) \\
\hline Impero (Empire) & Tenero (Tender) \\
\hline \multicolumn{2}{|l|}{ Matto (Crazy) } \\
\hline \multirow[t]{2}{*}{ Oro (Gold) } & Penna (Pen) \\
\hline & Inchiostro (Ink) \\
\hline Ago (Needle) & Scrivere (To Write) \\
\hline Filo (Wire) & Matita (Pencil) \\
\hline Puntura (Puncture) & Foglio (Sheet) \\
\hline Pagliaio (Haystack) & Biro (Biro) \\
\hline Punta (Tip) & Calamaio (Inkwell) \\
\hline Cucito (Sewing) & Nera (Black) \\
\hline Bilancia (Scales) & Piuma (Plume) \\
\hline Cucire (Sew) & Scrittura (Writing) \\
\hline Dolore (Pain) & Scuola (School) \\
\hline Abito (Dress) & Sfera (Sphere) \\
\hline Cammello (Camel) & Stilo (Stylus) \\
\hline Siringa (Syringe) & Astuccio (Case) \\
\hline Ditale (Thimble) & Grafia (Handwriting) \\
\hline Iniezione (Injection) & Oca (Goose) \\
\hline \multicolumn{2}{|l|}{ Pungere (Sting) } \\
\hline \multirow[t]{2}{*}{ Sarta (Seamstress) } & Piede (Foot) \\
\hline & Scarpa (Shoe) \\
\hline Uomo (Man) & Mano (Hand) \\
\hline Donna (Woman) & Scarpe (Shoes) \\
\hline Barba (Beard) & Collo (Neck) \\
\hline Forte (Strong) & Unghia (Nail) \\
\hline Genere (Gender) & Pianta (Plant) \\
\hline Persona (Person) & Ritmo (Rhythm) \\
\hline Adamo (Adam) & Sgabello (Stool) \\
\hline Onore (Honor) & Capo (Head) \\
\hline Bello (Handsome) & Dolere (Ache) \\
\hline Capelli (Hair) & Lungo (Long) \\
\hline Forza (Strength) & Marcia (March) \\
\hline Virile (Manly) & Spina (Plug) \\
\hline Cravatta (Tie) & Posare (Pose) \\
\hline Bambino (Child) & Zampa (Leg) \\
\hline
\end{tabular}




\section{Fumo (Smoke)}

Pipa (Pipe)

Sigaro (Cigar)

Sigaretta (Cigarette)

Tabacco (Tobacco)

Cenere (Ash)

Fumare (Smoke)

Nicotina (Nicotine)

Polmoni (Lungs)

Camino (Chimney)

Inquinamento (Pollution)

Cancro (Cancer)

Vapore (Steam)

Puzza (Stink)

Accendere (To Light)

Arrabbiato (Angry)

\section{Lento (Slow)}

Veloce (Fast)

Lumaca (Snail)

Andamento (Trend)

Ballo (Dance)

Treno (Train)

Adagio (Adagio)

Anziano (Elderly)

Calmo (Calm)

Ritardo (Delay)

Valzer (Waltz)

Sereno (Clear)

Tartaruga (Tortoise)

Piano (Peaceful)

Formica (Ant)

Pigro (Lazy)

Ragno (Spider)
Tela (Canvas)
Ragnatela (Spider Web)
Guadagno (Gain)
Insetto (Insect)
Zampe (Paws)
Animale (Animal)
Paura (Fear)
Mosca (Fly)
Amaca (Hammock)
Velenoso (Poisonous)
Buco (Hole)
Campagna (Contryside)
Fobia (Phobia)
Nero (Black)
Orrendo (Awful)

\section{References}

Anastasi, J. S., De Leon, A., \& Rhodes, M. G. (2005). Normative data for semantically associated Spanish word lists that create false memories. Behavior Research Methods, 37, 631-637. doi:10.3758/BF03192733

Anastasi, J. S., Rhodes, M. G., Marquez, S., \& Velino, V. (2005). The incidence of false memories in native and non-native speakers. Memory, 13, 815-828. doi:10.1080/09658210444000421

Brainerd, C. J., Yang, Y., Reyna, V. F., Howe, M. L., \& Mills, B. A. (2008). Semantic processing in "associative" false memory. Psychonomic Bulletin \& Review, 15, 1035-1053. doi:10.3758/PBR.15.6.1035

Deese, J. (1959). On the predication of occurrence of particular verbal intrusions in immediate recall. Journal of Experimental Psychology, 58, 17-22. doi:10.1037/h0046671

Gallo, D. A., McDermott, K. B., Percer, J. M., \& Roediger, H. L., III. (2001). Modality effects in false recall and false recognition. Journal of Experimental Psychology: Learning, Memory, and Cognition, 27, 339-353. doi:10.1037/0278-7393.27.2.339

Gallo, D. A., \& Roediger, H. L., III. (2001). Variability among word lists in eliciting memory illusions: Evidence for activation and monitoring. Journal of Memory and Language, 47, 469-497.

Madigan, S., \& Neuse, J. (2004). False recognition and word length: A reanalysis of Roediger, Watson, McDermott, and Gallo (2001) and some new data. Psychonomic Bulletin \& Review, 11, 567-573. doi: 10.3758/BF03196612

Marsh, R. L., McDermott, K. B., \& Roediger, H. L., III. (2004). Does testinduced priming play a role in the creation of false memories? Memory, 12, 44-55. doi:10.1080/09658210244000405

Norman, K. A., \& Schacter, D. L. (1997). False recognition in younger and older adults: Exploring the characteristics of illusory memories. Memory \& Cognition, 25, 838-848. doi:10.3758/BF03211328

Payne, D. G., Elie, C. J., Blackwell, J. M., \& Neuschatz, J. S. (1996). Memory illusions: Recalling, recognizing, and recollecting events that never occurred. Journal of Memory and Language, 35, 261-285.

Pérez-Mata, M. N., Read, J. D., \& Diges, M. (2002). Effects of divided attention and word concreteness on correct recall and false memory reports. Memory, 10, 161-177.

Roediger, H. L., III, \& McDermott, K. B. (1995). Creating false memories: Remembering words not presented in lists. Journal of Experimental Psychology: Learning, Memory, and Cognition, 21, 803-814. doi:10.1037/0278-7393.21.4.803

Roediger, H. L., III, Watson, J. M., McDermott, K. B., \& Gallo, D. A. (2001). Factors that determine false recall: A multiple regression analysis. Psychonomic Bulletin \& Review, 8, 385-407. doi:10. 3758/BF03196177

Seamon, J. G., Luo, C. R., \& Gallo, D. A. (1998). Creating false memories of words with or without recognition of list items: Evidence for nonconscious processes. Psychological Science, 9, 20-26.

Smith, R. E., \& Hunt, R. R. (1998). Presentation modality affects false memory. Psychonomic Bulletin \& Review, 5, 710-715. doi:10.3758/ BF03208850

Smith, R. E., \& Engle, R. W. (2011). Study modality and false recall: The influence of resource availability. Experimental Psychology, 58(2), 117-124. doi:10.1027/1618-3169/a000076

Stadler, M. A., Roediger, H. L., III, \& McDermott, K. B. (1999). Norms for word lists that create false memories. Memory \& Cognition, 27, 494-500. doi:10.3758/BF03211543

Zeelenberg, R., \& Pecher, D. (2002). False memories and lexical decision: Even twelve primes do not cause long-term semantic priming. Acta Psychologica, 109, 269-284. doi:10.1016/S0001-6918(01)00060-9 